УДК $811.161 .2^{\prime} 282.2$

\title{
РЕПРЕЗЕНТАЦІЯ НЕВЕРБАЛЬНОЇ ПОВЕДІНКИ В АРЕАЛЬНІЙ ФРАЗЕОЛОГІЇ УКРАЇНСЬКОЇ МОВИ
}

\author{
Ганна Демиденко
}

Криворізький державний педагогічний університет

Kryvyi Rih State Pedagogical University

пр. Гагаріна, 54, Кривий Ріг, 50086, Украӥна

demidenko_anna@ukr.net

\begin{abstract}
Демиденко Г. Репрезентація невербальної поведінки в ареальній фразеології української мови

У статті схарактеризовано структурно-семантичні моделі фразеологізмів, що побутують у говірках південно-східного наріччя, стосуються поняття “невербальна поведінка” і пов'язані з рухами тіла, позами, ходою, жестами, виразами обличчя, поглядом. 3'ясовано особливості вияву стилістичного забарвлення фразем, яке грунтується на емоційноекспресивному змісті компонентного складу висловів, а саме: у зв'язку 3 наявністю лексем зі згрубілим, вульгарним, фамільярно-розмовним маркуванням.

Ключові слова: південно-східне наріччя, діалектний фразеологізм, невербальна поведінка, жест, міміка, погляд.
\end{abstract}

Демиденко А. Репрезентация невербального поведения в ареальной фразеологии украинского языка

В статье анализируются структурно-семантические модели фразеологизмов, которые используются в говорах южно-восточного наречия, имеют отношение к понятию “невербальное поведение”, т. е. к движениям тела, позам, ходьбе, жестам, выражениям лица, взгляду. Определяются особенности стилистических оттенков фразем, которые базируются на эмоционально-экспрессивной составляющей компонентного состава устойчивых выражений, а именно: благодаря наличию лексем с грубой, вульгарной, фамильярно-просторечной маркированностью.

Ключевые слова: южно-восточное наречие, диалектный фразеологизм, невербальное поведение, жест, мимика, взгляд.

Demydenko G. Representation of non-verbal behavior in areal phrazeology of the ukrainian language

The article deals with the peculiarities of non-verbal behavior of Ukrainians, represented by regional idioms. Profound investigating of the systematic idiom

-21- Г. Демиденко, 2018. 
organization and operation is impossible without taking into account the detailed descriptions of both the literary language and dialects. The phraseology description of a certain region makes it possible to form relatively holistic representations of individual fragments of the phraseological system, the correlation of common and dialectal phraseology, its dynamics and innovative processes.

This research is focused on the set expressions, which are not recorded in dictionaries, or modified ones. The subject of the study is the dialectal phraseology of the southeastern dialect. On the basis of regional speaking practice, the knowledge of non-verbal communication components and the peculiarities of interpersonal interaction are revealed. It is determined that non-verbal protoword signs form the basis of human speaking. With the advent of verbal language, they do not disappear altogether, but go deep into the individual linguistic consciousness, representing the important elements of national culture, character, social interactions, traditions, etc.

This paper describes the structural and semantic models of idioms related to the concept of "non-verbal behavior", especially those ones related to body movements, posture, motion, gestures, facial expressions, peculiarities of the eyesight. Investigating the structural and semantic features of the analyzed set expressions allows reconstructing the meaning of prototype communication situations in the Ukrainian dialectal linguistic environment.

Key words: southeast dialect, dialect idiom, non-verbal behavior, gesture, facial expression, vision.

\section{Постановка проблеми та її зв'язок із важливими} науковими завданнями. Упорядкування фразеологічного багатства різних регіонів України є важливим і необхідним завданням сучасної лексикографічної та фразеографічної практики.

Аналіз останніх досліджень та публікацій. На сьогодні фразеографія говірок представлена окремими словниками й опублікованими фрагментами словників діалектної фразеології, що засвідчено працями вітчизняних діалектологів (Г. Аркушин, Я. Битківська, Н. Вархол, О. Вікторіна, Т. Грица, П. Грищенко, Г. Доброльожа, М. Доленко, А. Івченко, Н. Кірілкова, Н. Коваленко, Л. Корнієнко, З. Мацюк, Р. Міняйло, О. Плетнєва, О. Романюк, Г. Ступінська, В. Ужченко, Д. Ужченко, В. Чабаненко, О. Юрченко та ін.).

Важливими на цьому етапі науково-прикладної роботи $\epsilon$ інтерпретація фразеологічного значення, відбір матеріалу, принципи тлумачення, наявність культурологічного коментаря тощо. Однак не менш важливими є опис певних культурно 
детермінованих явищ, зокрема мова йде про специфічні риси міжособистісної комунікації, відображені ареальними фраземами української мови. Серед непересічних компонентів людського спілкування цікавою й недостатньо вивченою $\epsilon$ невербальна поведінка мовців. За таких умов дослідження вияву невербальної взаємодії представників української лінгвоспільноти окремих територій виявляється досить перспективним і складає актуальність пропонованої розвідки.

Мета й завдання дослідження. Мета статті полягає у з'ясуванні особливостей діалектних фразеологічних одиниць (далі - ФО) на позначення невербальної поведінки, що узагальнено позначають фрагменти дійсності, асоційовані з певними рухами тіла, позами, ходою, виразами обличчя, особливостями погляду, жестами тощо.

Виклад основного матеріалу дослідження. Українська діалектна фразеологія багата на вислови, у яких передається внутрішній стан людини, ії думки, почуття, бажання за участю зорового аналізатора. Такий когнітивний процес у лінгвістичному контексті можна розглянути завдяки семантичному навантаженню атрибутивних характеристик погляду, як-от: пильний, злий, здивований, зляканий, уважний, зацікавлений.

Найвищу продуктивність виявляють сталі звороти, які демонструють почуття здивування, заздрості, гніву, страху, що, як відомо, можуть супроводжуватися змінами розміру очей, збільшенням зіниць, підняттям брів. Наприклад, здебільшого у зневажливому контексті вживається вислови вилупити бельки (5, с. 26; 5, с. 55); бебеки (бебики) витрімати (4, с. 55); бельми витріщуати (4, с. 56) беньки витаращати (4, с. 56); беньки витріщчити (4, с. 56); витріщати боцаки (4, с. 69) вивалити (вилупити) беньки (2, с. 10); витріщчити [свої] балуц̧ки (баньки) $(2$, c. 10). Семантичний обшир наведених прикладів ілюструє здебільшого здивування, заздрість, а вислови вживаються у зневажливому значенні. Із іронічною оцінкою процесу споглядання за кимось пов'язаний сталий зворот витріщати вишеньки (2, с. 94), який сформувався на основі метафоричного перенесення, зважаючи на подібність круглої форми плоду 
вишні 3 фізіологічною реалією широко розплющених i збільшено округлених очей.

Емоцію здивування репрезентує й ФО очі на орбіті $(4$, c. 367), що утворилася завдяки перенесенню зовнішнього вигляду збільшених очей та уявленню про значний розмір орбіти Землі. Окрім того розвиток образної семантики можна уявити приблизно й так: розплющити очі надто широко “вивести” їх за межі нормального фізіологічного розташування на обличчі, а, отже, змінити просторові орієнтири (“вийти 3 орбіти”). Зорові образи виявляються й у висловах, в основі метафоричного перенесення яких може бути значення предметів круглої форми, зокрема монет, наприклад: очі по восім копійок (4, с. 367); очі по n'ятдесят копійок (4, с. 367); очі по n'ять (щість, сім) копійок (4, с. 367); зробити великі очі по n'ять копійок (4, с. 365). Як зазначає В. Ужченко, вислів зробити великі очі по n'ять копійок є результатом контамінації двох фразеологізмів із значенням “здивуватися": зробити великі очі + зробити очі по п'ять копійок $(4$, с. 365$)$.

На позначення прискіпливого, уважного, пильного погляду в південно-східному наріччі побутують фраземи: баньки ганяти (дути) (4, с. 50); баньки дути (4, с. 50); беньки вивалювати (1, с. 21); беньки (бені) ганяти (1, с. 138). Як демонструє фактичний матеріал, переважно задля номінації очей використовується лексеми баньки, беньки, бельки, бельми, боцаки, балуц̧ки, що надають висловам вульгарного звучання, знижуючи їх стилістичний потенціал до просторіччя [Velykyi / Великий 2009: 61]. Поданим зневажливим i згрубілим лінгвоодиницям властивий знижений стилістичний план, як i загалом зворотам у межах діалектної фразеології, підсилений оцінним стилістичним забарвленням компонентів ФО.

Фразеографічні джерела фіксують звороти, які демонструють злий, недобрий, зурочливий погляд: взгляд сизий $(1$, с. 32$)$; зизе око $(1$, с. 137$)$; дивитися биком $(4$, с. 58$)$ та ін. Такі лінгвоодиниці засвідчують несхвальне ставлення до співрозмовника, неприязнь, подекуди заздрість, що відповідає українській культурній традиції, адже, за народними повір'ями, “зле” око здатне завдати людині шкоди, має негативний вплив i 
тому такого погляду варто остерігатися [Zhaivoronok / Жайворонок 2006 : 415]. Про особливості погляду свідчить й лексема зизий - діалектний варіант лексеми косий [Velykyi / Великий 2009 : 459] на позначення бокового зору задля передачі певного ставлення, здебільшого негативного. В академічному фразеологічному словнику натрапляємо на вислів кривий погляд - “підозра, неприязнь" (3, с. 527) атрибутивна ознака кривий вступає в синонімічні відношення $з$ лексемою косий (зизий).

Значно меншу частотність у діалектному мовленні виявляють фразеологізми, що ілюструють тривалий погляд, як-от: очі повипадають (4, с. 367); очі поламати (порвати) (4, с. 368); очі рвати (4, с. 368) тощо. Такі сталі звороти передають не тільки часові проекції сприйняття особою чогонебудь, але й кваліфікують особливості емоційного стану співрозмовника, який хвилюється, нетерпляче виглядає когось, очікує на щось. На такі внутрішні переживання, емоційну насиченість погляду вказують дієслова поламати, порвати, повипадають, смисловий діапазон яких зосереджений на відображенні стану зіпсованості, непридатності до подальшого використання, зруйнованості.

Емоційні переживання передані й іншими сталими зворотами, що омовлюють стан зацікавлення кимось, закоханість: басіки пускати (4, с. 51); розкидати (порозкидати) очі (4, с. 368). В українській мові кокетство як поведінкова реакція представлена такими ФО, як-от: посилати бісики (3, с. 547); пускати бісики [очима (оком)] (3, с. 584), у межах діалектної фразеології південно-східних регіонів натрапляємо на варіант басіки пускати.

Трапляються й фраземи із семантикою неробства, а саме клепати очима, що значить “ледарювати” (4, с. 366), де дієслово клепати пов'язане із фізичним впливом на метал (удари, з'єднування металевих частин, кування металу). Як бачимо, метафоричне переосмислення дій, виконуваних очима, $\epsilon$ свідченням перенесення частини емпіричного досвіду з роботи ковалів, адже постійний одноманітний рух молотом по ковадлу і рух людських повік мають схожу амплітуду. Такий неквапний, 
розмірений рух характерний для очей, якщо людина неперевантажена роботою, перебуває у спокої, у стані дрімоти.

В аспекті дослідження реалізації невербальної поведінки українців засобами фразеології заслуговують на увагу такі ФО, уживання яких стосується ілюстрацій візуальних змін обличчя людини і його частин. У такому разі Ш. Баллі називав міміку непрямим, невтіленим у слові засобом, який впливає на співрозмовника більше, ніж вербальна мова. Він зазначав, що паралінгвальні явища “сприяють злиттю відчуттів та емоцій 3 інтелектуальною стороною висловлювання, адже тільки завдяки такому злиттю так звані живі мови дійсно $є$ живими" [Bally / Балли $1961: 118]$.

Д. Кузнєцова запропонувала парадигму розгляду цього невербального знака емоцій у мовознавчому ключі, виокремивши такі основні позиції: “1) лицеві вияви - комплекс різних мімічних рухів, який сприймається недискретно; 2) лицеві жести, що демонструють динамічний аспект виразів обличчя; 3) вияви психофізіологічних реакцій на обличчі, наприклад, неконтрольовані вегетативні зміни кольору шкіри" [Kuznietsova / Кузнєцова 2009 : 8]. 3 позицій такого підходу й зважаючи на проаналізований мовний матеріал, фразеологізми на позначення лицевих жестів можна розглянути в межах таких груп: 1) ФО, які вказують на певну конфігурацію рота або положення губ; 2) ФО, що уточнюють нефіксовану візуально пластику кінем зони носа; 3) ФО, які маніфестують зміни міміки, зумовлені маніпуляціями 3 зубами; 4) ФО, що репрезентують вираз обличчя загалом, зокрема й пов'язані зі комунікативно значущими змінами кольору шкіри.

Найчастотнішими у проаналізованих фразеографічних працях є сталі звороти, що називають рухи губ і рота. У таких стійких образах-фразеологізмах відображуються найрізноманітніші емоції, психічний і фізичний стан людини [Uzhchenko / Ужченко 2007 : 175]. Наприклад: образа, гнів (губи накопірчувати (1, с. 57); губи дуть (1, с. 57); надути (одтопирити, одкопилити) вареники (4, с. 84); нахлобучити губи (4, с. 161); накопичити [свої] губи (4, с. 161); одтопирити губи (4, с. 161); чванство, пиха (губи вище носа копилити 
(1, с. 57); губи дуть (1, с. 57); захоплення, подив (pom роздівлять (1, с. 167), веселощі, сміх (губу (губи) розкатати (4, с. 160); надмірні бажання (розкатати губи на вареники (4, c. 161).

Українська народна етика й мораль засуджують такі негативні риси характеру як пиха, злість, надмірна гоноровість, що досить яскраво ілюструють губи, адже саме “по губах угадують настрій, поведінку людини” [Zhaivoronok / Жайворонок 2006 : 160]. Як свідчить спостереження над мовним матеріалом, значення міміки губ фіксується насамперед двокомпонентними конструкціями 3 формально опорним елементом, вираженим дієсловами: накопірчувати, копилити, надути, одтопирити, одкопилити, накопичити, нахлобучити. Скажімо, когнітивний сценарій утворення вислову губи вище носа копилити $(1$, с. 57) пов'язаний із зоровими образами вип'ячених губ, які людина здіймає максимально високо і тим самим демонструє співрозмовнику свою зверхність, на що вказує лексема копилити - “випинати, надувати (зазвичай, губи)" [Velykyi / Великий 2009 : 572].

Вислови губи накопірчувати (1, с. 57); губи дуть (1, с. 57); накопичити [свої] губи (4, с. 161); накопучити [свої] губи (4, с. 161); нахлобучити губи (4, с. 161); одтопирити губи (4, с. 161); надути (одтопирити, одкопилити) вареники маніфестують особливості мімічної дії, де жестикулянт виставляе (вип'ячує) уперед нижню губу, що вказує на несвідомий вираз дитячого обличчя, характерного для моменту плачу, незадоволення. Такий невербальний акт властивий дорослій людини, яка прагне, аби іï заспокоїли, утішили, вчинили згідно з ії бажаннями.

На окреме коментування заслуговують сталі звороти надути (одтопирити, одкопилити) вареники (4, с. 84), розкатати губи на вареники (4, с. 161), у структурі яких соматизм губи змінено на іменник вареники, уживаний на позначення великих губ (4, с. 84). Подібні вислови не зафіксовано в академічному фразеологічному словнику, що вкотре свідчить про розмовний, стилістично знижений характер діалектних ФО. Як бачимо, наведені лінгвоодиниці 
вирізняються яскравою предметною образністю, містять в основі денотата метафору, пов'язану з глютонімом вареник, що належить до традиційної української кухні. 3 подібними мімічними втіленнями пихи й зазнайства мають зв'язок і сталі звороти хоч бублик чіпляй $(4$, с. 74$)$; кидати носом $(4$, с. 352) 3 наявним або відсутнім соматизмом ніс у структурі вислову.

Значно меншу частотність виявляють фразеологізми, які репрезентують зміни міміки, зумовлені маніпуляціями з зубами: виставити [всі] тридиять два [зуби] (4, с. 93); блищати зубами (4, с. 223); світити зубами (4, с. 225). Наведені приклади ілюструють посмішку як “особливий порух м'язами обличчя (губ, очей), який виражає схильність до сміху”, [Velykyi / Великий $2009: 1080]$ або певне ставлення до співрозмовника (прихильність, зацікавленість, глузування, кепкування тощо). Мімічні рухи губами 3 демонстрацією зубів почасти синтезують культурно-національну інформацію про смерть людини, що засвідчено у вислові усміхнутися на кутні у значенні “померти” (4, с. 296).

Реалізовує певну комунікативну програму й вираз обличчя загалом, зокрема інформативними $\epsilon$ симптоматичні вияви емоцій і почуттів, здебільшого мова йде про зміну кольору шкіри. Наприклад вираз обличчя фіксують вислови на кшталт морда кирпичом (1, с. 132); морда кирпичем (4, с. 338); морда на морозі $(4$, с. 338$) ;$ морда віником $(4$, с. 338$)$ та ін. Ця група аналізованих просторічно-згрубілих фразем містить соматизм морда з вульгарним, експресивно-оцінним забарвленням, що підсилює значення ФО і досить образно характеризує нахабну, хвалькувату людину, яка вдає емоції задля певної вигоди. Подекуди натрапляємо на сталі звороти на зразок щзоки пижить $(1$, c. 222), який уживається задля глузливої номінації людини, що зазнається, бундючитися й активно при цьому рухає щоками. Вислів аж з виду перемінитися, що означає “дуже хвилюватися, перейматися” (1, с. 33), позбавлений соматичних компонентів у структурі, тому обриси мімічної картини в подібній ситуації спілкування комунікатори сприймають зазвичай інтуїтивно, аналізуючи загальне емоційне тло міжособистісної взаємодії. 
Оскільки вияв емоції на обличчі виступає маркером іiі переживання людиною, то варто назвати фразеологічні номінації вияву психофізіологічних реакцій на обличчі, що позначають зміни кольору шкіри. В опрацьованій лексикографічній літературі натрапляємо на вислови, що ілюструють лише процес почервоніння: кинутися в краску (4, с. 283); ударитися в краску (4, с. 284) та ін.

На тлі проаналізованих ФО і в їх контексті виразніше сприймається й образний зміст висловів, пов'язаних 3 рухами тіла людини, особливостями ходи. У досліджуваних працях кількісно найбільш представленими $\epsilon$ сталі звороти на позначення процесу ходіння, у яких відповідне дієслово руху наявне у структурі, а саме: павліном ходить (1, с. 140); петухом ходить (1, с. 144); півнем ходити (4, с. 385); ходити гускою (4, с. 163); ходить наприсядки (1, с. 207) та ін. Здебільшого подані фраземи можна розглядати крізь призму соціального збайдужіння, цурання, 3 іронією і глузуванням, загальне несхвалення отримують поведінкові реалії, як-от: вияв неповаги, чванство, приниження, догоджання комусь тощо. Внутрішня форма цих одиниць указує на особливості поведінки гордої, улесливої людини, зокрема порівняно 3 діями інших представників тваринного світу. Подібну специфіку ходи вбачаємо й у ФО: держати (дерти) хвіст крючком (4, с. 508); держати (дерти) хвіст пістолетом (4, с. 508); держати хвіст трубою $(4$, с. 508$)$.

У звороті як на шрубах, що означає “дуже жваво, постійно” (4, с. 540) дієслівний компонент ходити перебуває в лексичному оточенні ФО, а фразеотворчу роль відіграє лексема шруб (шруба), що є діалектним варіантом до шурупа, гайки [Velykyi / Великий 2009 : 1631]. На нашу думку, цей вислів грунтується на реальних життєвих спостереженнях за дією механізмів, у складі яких є гайки, гвинти й подібні залізні елементи задля покращення, пришвидшення, довготривалості pyxy.

Спостереження за семантикою й структурою ФО на позначення невербальної поведінки українців засвідчують й інші номінації рухів різними частинами тіла, тулубом загалом. 
Так, про кивання головою зафіксовано у фраземі кивати головою як корова в Спасівку (4, с. 137). У східнослобожанських і степових говірках такий рух головою у свійських тварин апелює до свята Спасівка, яке випадає на кінець літа, і мухи надзвичайно злі, вони готуються відкладати яйця, їм потрібна кров, тому вони в цей час особливо кусючі $(4$, с. 137).

Про позитивні емоції, сміх, радість свідчать рухи руками ([аж] за поли братися (4, с. 397) і стрибки (стрибати боком (4, с. 61). Цікаво, що зворот [аж] за поли братися $(4$, с. 397) позбавлений соматичного компонента. Отже, про відповідну дію руками можна здогадатися звертаючи увагу на дієслівний компонент братися (“хапатися рукою” [Velykyi / Великий 2009 : 95]) i лексему пола (“край кожної з половин одягу (пальта, шинелі, піджака і т. ін.), що розгортається спереду” [Velykyi / Великий 2009: 1030]). Така частина одягу перебуває в безпосередньому контакті 3 тулубом i в межах ФО сприймаються з ним як єдине ціле.

На фамільярну поведінку людини вказує зворот ногою двері відкривати (одкривати) (4, с. 357), пов'язаний із міжособистісною взаємодією з посадовцями, коли особа ставить себе 3 ними на однин рівень. Такий рух ногами $є$ фізично можливим, але 3 позиції етики ділового спілкування $\epsilon$ неприпустимим навіть у неформальному спілкування керівника й підлеглого.

3-поміж аналізованих лінгвоодиниць натрапляємо на вислів з етнографічним маркуванням поклонитися батькам, що означає "подякувати батькам по закінченні весілля" (4, с. 53). Такий рух тулуба $є$ знаком динамічної етикетної експресії і постає традиційним у комунікативній практиці українців на знак поваги. Як стверджують етнографічні дослідження, варто низько кланятися за зроблене добре діло, а характерною рисою гостинності вважають легкий уклін; низькі поклони здійснює наречена, коли запрошує на весілля, і молоді - батькові-матері на самому весіллі [Стахів / Stakhiv 2008: 105-106]. Спостереження за специфічними рухами всього тіла, пов'язаними з фізіологічним виявом злості, стану знервованості відображені у фраземі бециики б'ють (4, с. 57), де лексема бециики 
позначає “назву дитячої гри в крем'яшки” [Москаленко / Moskalenko 1958: 16], а власне дієслово бецүкатися фіксує словник гуцульських говірок у значенні “1) гездатися (про худобу); 2) перен. нервувати, сердитися” [Hutsulski / Гуцульські $1997: 24]$.

Особливості положенням тіла у просторі репрезентують ФО: проковтнути голоблю (4, с. 134); як гуска на мотоциклі (4, с. 163); сидіти нога за ногу $(4$, с. 359) й ін., уживані в жартівливому й іронічному контексті. Скажімо, вислів проковтнути голоблю означає “ходити, сидіти неприродно рівно, виструнчено або застигти в неприродній позі” (4, с. 134). Як зазначають фразеологи-діалектологи В. Ужченко, Д. Ужченко, в основу виразу покладене жартівливе уявлення про те, що голобля, яку проковтнула людина, заважає ій прийняти природну позу (4, с. 134). Про незручну позу сидіння свідчить сталий зворот як гуска на мотоциклі (4, с. 163), що виник на основі прототипової ситуації й гумористичного образу гуски у відповідному транспортному засобі. Можемо припустити, що такі прецеденти траплятися колись 3 кимось і створили образ для подальшої фразеологізації.

Окрему підгрупу діалектних фразеологізмів складають вислови на позначення жестів. Розглянутий фактичний матеріал дає підстави деталізувати ФО, внутрішня форма яких пов'язана з рухами пальців, адже зафіксовані одиниці являють собою сталі звороти саме 3 цим соматизмом. Наприклад, стійкі звороти пальці вєєром (4, с. 372); пальці вєєром, зуби шифером (4, с. 372); пальці вєєром, соплі пузирями (4, с. 372); пальиі вєєром, зуби шифером, а соплі пузирями (4, с. 373) мотивовані поведінкою дуже гордовитої, пихатої, неприступної людини і репрезентують, окрім невербальних рухів, й інші фізіологічні процеси, притаманні такій особі під час емоційного збудження чи безпосередньо соціального домінування в комунікативних ситуаціях.

B українському комунікативному просторі явище неробства реалізується різними невербальними знаками. Як свідчить аналіз фразеографічних праць й у зв'язку з викладеним вище, ледарство i бездіяльність виявляються як через 
особливості зорової взаємодії, пози людини, так і рухами пальців у висловах пальці м'яти (мняти) (4, с. 373); голубам дулі давати (4, с. 140) (пор. 3 ФО давати горобиям дулі (3 с. 176) та ін.

Серед жестових фразем цікавими є такі лінгвоодиниці, які називають певні комбінації з пальців (дулю показувать (1, с. 72); голубам дулі давати (4, с. 140) або їх загальну сукупність (держати (тримати) кулаки (4, с. 290). Культурно детермінованими постають у мовленні й фраземи на позначення соціально неприпустимих, образливих жестів, таких як дуля. Прикметно, що вислів дулю показувать означає "не погоджуватися, не виконувати, піддурювати" (4, с. 72) і набуває негативної оцінки в діалектному вживанні, очевидно, й у зв'язку зі символікою відповідного жесту. В академічному словнику української мови натрапляємо на вислів показувати дулю (фігу) (3, с. 532) з відмінною семантикою, а саме: “відмовити комунебудь у чомусь, нічого не дати, не допомогти і т. ін.”.

Особливості жестів-прикмет відображено у звороті держати (тримати) кулаки, який означає "полегшувати собі у здійсненні чогось”. Згідно 3 дослідженнями фразеографів, побутує вірування, що названий жест нібито допомагає в рішучі моменти (4, с. 290). Як нам видається, асоціації стиснутого кулака 3 виявом сили, іiі акумулюванні у прихованому, “згорнутому” вигляді стали психологічною передумовою для виникнення жестової одиниці, що у свою чергу стала підгрунтям для утворення фраземи. Дещо інакшу реалізацію жесту вбачаємо у вислові збиратися (складатися) в [один] кулак "напружувати, концентрувати всі сили, волю, витримку, згуртованість" (3, с. 257). Зіставні коментарі дають змогу визначити відмінності діалектних фразем та тлі загальномовних одиниць, упорядкованих в академічному словнику.

Висновки та перспективи подальших наукових розвідок. Невербальні засоби спілкування (жести, міміка, погляд, хода, поза) не залишаються осторонь, коли людина намагається втілити в мові ті психічні образи, що виникають як результат спостережень над навколишнім світом, поведінкою окремих індивідів, їх свідомих чи несвідомих рухів тощо. За 
таких умов стійкі вислови - це образна вторинна номінація реалій i, звичайно, ситуацій, пов'язаних 3 невербальною поведінкою мовців в межах окремих наріч української мови.

Уважаємо перспективними подальші дослідження діалектної фразеології інших регіонів задля виявлення специфічних рис характеру українців, відмінних і спільних номінації невербальної поведінки, що як частина життя людей, вагома складова їх спілкування стала джерелом фраземотворення.

\section{Література}

1. Балли Ш. Французская стилистика. Москва : Изд-во иностранной литературы, 1961.394 с.

2. Великий тлумачний словник сучасної української мови / уклад. і голов. ред. В. Т. Бусел. Київ-Ірпінь : ВТФ Перун, 2009. 1736 с.

3. Гуцульські говірки. Короткий словник / відп. ред. Я. Закревська. Львів : Вид-во Львівської обл. книж. друк., 1997. 232 с.

4. Жайворонок В. Знаки української етнокультури : словник-довідник. Київ : Довіра, 2006. 703 с.

5. Кузнєцова Д. Ю. Номінативне поле “вираз обличчя” в сучасному англомовному дискурсі : емотивний та прагматичний аспекти : автореф. дис. ... канд. філол. наук : 10.02.04. Київ, 2009. 22 с.

6. Москаленко А. А. Словник діалектизмів українських говірок Одеської області. Одеса : Вид-во ОДПУ ім. К. Д. Ушинського, 1958. 76 с.

7. Стахів М. Український комунікативний етикет : навч.-метод. посіб. Київ : Знання, 2008. 245 с.

8. Ужченко В. Д., Д. В. Ужченко Фразеологія сучасної української мови : навч. посіб. Київ : Знання, 2007. 494 с.

\section{Список використаних джерел}

1. Матеріали до фразеологічного словника Центральної Слобожанщини (Харківщини) / автор-упор. А. А. Сагаровський. Харків : ХНУ імені В. Н. Каразіна, 2015. $228 \mathrm{c.}$

2. Плетнєва О. Фразеологія говірок центральної Слобожанщини (структурно-семантичний аспект) : автореф. дис. ... канд. філол. наук. Харків 2004. $25 \mathrm{c}$.

3. Словник фразеологізмів української мови / уклад. В. М. Білоноженко та ін. Київ : Наукова думка, 2003. 1104 с.

4. Ужченко В. Д., Ужченко Д. В. Фразеологічний словник східнослобожанських і степових говірок Донбасу. Луганськ : Вид-во ДЗ “ЛНУ ім. Тараса Шевченка", 2013. 552 с.

5. Чабаненко В. Фразеологічний словник говірок Нижньої Наддніпрянщини. Запоріжжя, 2001. 201 с. 


\section{References}

1. Bally Sh. Frantsuzskaia stilistika. Moskva : Izd-vo inostrannoi literatury, 1961. $394 \mathrm{~s}$.

2. Velykyi tlumachnyi slovnyk suchasnoi ukrainskoi movy / uklad. i holov. red. V. T. Busel. Kyiv-Irpin : VTF Perun, 2009. 1736 s.

3. Hutsulski hovirky. Korotkyi slovnyk / vidp. red. Ya. Zakrevska. Lviv : Vydvo Lvivskoi obl. knyzh. druk., 1997. 232 s.

4. Zhaivoronok V. Znaky ukrainskoi etnokultury : slovnyk-dovidnyk. Kyiv : Dovira, 2006. $703 \mathrm{~s}$.

5. Kuznietsova D. Yu. Nominatyvne pole "vyraz oblychchia" v suchasnomu anhlomovnomu dyskursi : emotyvnyi ta prahmatychnyi aspekty : avtoref. dys. ... kand. filol. nauk : 10.02.04. Kyiv, 2009. $22 \mathrm{~s}$.

6. Moskalenko A. A. Slovnyk dialektyzmiv ukrainskykh hovirok Odeskoi oblasti. Odesa : Vyd-vo ODPU im. K. D. Ushynskoho, 1958. $76 \mathrm{~s}$.

7. Stakhiv M. Ukrainskyi komunikatyvnyi etyket : navch.-metod. posib. Kyiv : Znannia, 2008. $245 \mathrm{~s}$.

8. Uzhchenko V. D., Uzhchenko D. V. Frazeolohiia suchasnoi ukrainskoi movy : navch. posib. Kyiv : Znannia, 2007. $494 \mathrm{~s}$.

\section{Spysok vykorystanykh dzherel}

1. Materialy do frazeolohichnoho slovnyka Tsentralnoi Slobozhanshchyny (Kharkivshchyny) / avtor-upor. A. A. Saharovskyi. Kharkiv : KhNU imeni V. N. Karazina, 2015. $228 \mathrm{~s}$.

2. Pletnieva O. Frazeolohiia hovirok tsentralnoi Slobozhanshchyny (strukturnosemantychnyi aspekt) : avtoref. dys. ... kand. filol. nauk. Kharkiv 2004. 25 s.

3. Slovnyk frazeolohizmiv ukrainskoi movy / uklad. V. M. Bilonozhenko ta in. Kyiv : Naukova dumka, 2003. $1104 \mathrm{~s}$.

4. Uzhchenko V. D., Uzhchenko D. V. Frazeolohichnyi slovnyk skhidnoslobozhanskykh i stepovykh hovirok Donbasu. Luhansk : Vyd-vo DZ "LNU im. Tarasa Shevchenka", 2013. 552 s.

5. Chabanenko V. Frazeolohichnyi slovnyk hovirok Nyzhnoi Naddniprianshchyny. Zaporizhzhia, 2001. $201 \mathrm{~s}$.

Стаття надійшла до редакиії 17.06.2018 р. Прийнята до друку 15.11. 2018 р. 